\title{
Examining the Possibilities for Efficiency Improvement of SMED Method Using Simulation Modelling
}

Péter Tamás

Institute of Logistics, University of Miskolc, 3515 Miskolc-Egyetemváros, Hungary, alttpeti@uni-miskolc.hu

We can reach significant results in the field of waste reduction in production processes with application of the tool and rule systems of lean philosophy. One of the frequently applied lean methods is SMED (Single Minute Exchange of Die), which is able to reduce the changeover times and the resulting wastes. Length of the changeover time has a relevant effect on several parameters of the production process (inter-operational inventories, batch sizes, production lead time, manufacturing flexibility, etc.), consequently its reduction is an important competitive factor for a companies. The paper introduces in detail the role of the set-up time in production logistics and its reduction possibilities in real-life situations as well. We examined and summarized the application possibilities of simulation modelling for the efficiency increase of the SMED method as well.

Keywords: SMED, process improvement, simulation

\section{Acknowledgement}

This project has received funding from the European Union's Horizon 2020 research and innovation programme under grant agreement No 691942". This research was (partially) carried out in the framework of the Centre of Excellence of Mechatronics and Logistics at the University of Miskolc.

\section{References}

[1] CSELÉNYI, J., ILLÉS, B. (2006). Planning and Controlling of Material Flow Systems. Textbook, Miskolci Egyetemi Kiadó.

[2] WOMACK, J. P., JONES, D. T. (2008). Lean Thinking, Simon \& Schuster Inc., 2008.

[3] BICHENO, J., HOLWEG, M. (2008). The Essential Guide to Lean Transformation. Picsie Books, 2008

[4] ROTHER, M., SHOOK, M., J. (2003). Learning to See: Value Stream Mapping to Add Value and Eliminate Muda, Lean Enterprise Institute

[5] KOVÁCS, GY. (2012). Productivity improvement by lean manufacturing philosophy, Advanced Logistic Systems: Theory And Practice 6:(1) pp. 9-16.

[6] WILSON L. (2010). How to Implement Lean Manufacturing, McGraw-Hill Companies, Inc., 2010, ISBN 978-0$07-162507-4$

[7] GLiStAU, E., NORGE MACHADO, I. C., Illés, B. (2014). Logistics planning process and Kanban, 28th microCAD Nemzetközi Multidiszciplináris Tudományos Konferencia $=28$ th microCAD International Multidisciplinary Scientific Conference. Miskolc: University of Miskolc, 2014. Paper C4.

[8] SHINGO, S. (1985). A Revolution in Manufacturing. The SMED System. Productivity Press, 1985

[9] KOSZTOLÁNYI, J., SCHWAHOFER, G.: Kanban, KAIZENPRO Oktató és Tanácsadó Kft., 2012.

[10] ULUTAS, B. (2011). An application of SMED methodology, International Journal of Mechanical, Aerospace, Industrial, Mechatronic and Manufacturing Engineering Vol:5, No:7

[11] KUNDRÁK J, MARKOPOULOS A. (2016). FEM/AI models for the simulation of precision grinding, Manufacturing Technology 16:(2) pp. 384-390.

[12] GRABCHENKO A., FEDOROVICH V., PYZHOV I., KUNDRÁK, J. (2014). 3D simulation of vibrating diamond grinding, Manufacturing Technology (ISSN: 1213-2489) 14: (2) pp. 153-160. 